\title{
Nanostructured Semiconducting Metal Oxides for Ammonia Sensors. A Novel HSAB Sensing Paradigm
}

\author{
Bogdan-Catalin Serban, ${ }^{1,{ }^{*}}$ Octavian Buiu, ${ }^{1}$ Cornel Cobianu, ${ }^{1}$ \\ Mihai Brezeanu, ${ }^{2}$ Marius Bumbac ${ }^{3}$ and Cristina Mihaela Nicolescu ${ }^{4}$ \\ ${ }^{1}$ National Institute for Research and Development in Microtechnologies, IMT-Bucharest, 126 A Str Erou Iancu Nicolae, \\ 077190, Voluntari, Ilfov, Romania \\ ${ }^{2}$ University Politehnica of Bucharest, Romania, Faculty of Electronics, Telecommunications and IT, \\ 313 Splaiul Independentei, Sector 6, 060042, Bucharest, Romania \\ ${ }^{3}$ Valahia University of Targoviste, Faculty of Sciences and Arts, Sciences and Advanced Technologies Department, \\ 2 Bd. Carol I, 130024, Targoviste, Dambovita, Romania \\ ${ }^{4}$ Valahia University of Targoviste, Institute of Multidisciplinary Research for Science Technology, 2 Bd. Carol I, 130024, \\ Targoviste, Dambovita Romania \\ *Corresponding author: E-mail: bogdan.serban@imt.ro \\ Tel: +40724284128
}

Received: 25-06-2018

\begin{abstract}
The paper demonstrates how the Hard-Soft Acid Base (HSAB) theory can be used as a valuable criterion in the selection process of semiconducting metal oxides (MOX) suitable as sensing layers for ammonia detection. Six different cases of ammonia detection performed by chemiresistive sensors employing MOX and related nanocomposites as sensing layers are identified and discussed. The role of HSAB as an efficient selection tool for appropriate sensing layer (any type of gas), is further reinforced by analyzing and discussing literature results on MOX-based trimethylamine sensing layers. By analyzing the operation of a fiber-optic ammonia sensor, we demonstrate that the HSAB principle can be also successfully applied to the selection of sensing layers for detectors employing other sensing principles, different than the chemiresistive one. Changing the sensing paradigm (i.e., the amino groups-based compounds are part of the sensing layer, rather than part of the analyte), the paper shows that these types of molecules (polymers, carbon nanotubes, ionic liquids) are appropriate constituents of a $\mathrm{CO}_{2}$ sensing layer, in full accordance to the HSAB criteria.
\end{abstract}

Keywords: MOX; HSAB; ammonia; sensor; nanostructure; carbon dioxide.

\section{Introduction}

Ammonia $\left(\mathrm{NH}_{3}\right)$, a natural gas that is present throughout the atmosphere, is a highly toxic compound, with low odor threshold (20 ppm), corrosive to the skin, eyes, throat and lungs. The most widely recognized exposure limits for ammonia are an eight-hour TWA (Time Weighted Average) of $25 \mathrm{ppm}$, with a 15-minute STEL (Short Term Exposure Limit) of $35 \mathrm{ppm} .{ }^{1}$ Strong irritation of the nose and throat occurs at $500 \mathrm{ppm}$, while exposure to $1000 \mathrm{ppm}$ or more causes lungs injury (pulmonary edema). ${ }^{2-3}$ Extremely high concentrations, around $5000-10,000 \mathrm{ppm}$, are fatal to humans within the first 5-10 minutes of exposure. ${ }^{4}$
Ammonia, one of the most important industrial raw materials in the world, is widely used in many industries including chemical and petrochemical, food/beverage, pulp and paper, fertilizer and the oil industry, pharmaceuticals, etc. Its global production exceeds 100 million tons per year. Ammonia is also the key precursor in the synthesis of many chemical compounds with high economic value, such as urea (Bosch -Meiser process), hydroxilamine and ammonium carbonate (Raschig process), acrylonitrile (Sohio process), hydrazine (Olin Raschig process), ammonium nitrate, hexamethylenetetramine, to name but a few. ${ }^{5}$ Anhydrous ammonia is also extensively 
used as a coolant in industrial refrigeration systems, replacing environmentally unfriendly chlorofluorocarbon refrigerants. It is worth mentioning that ammonia is an ingredient in the formulation of many cleaning products. ${ }^{6}$

Given all the above, sensing of ammonia is an important process in various areas of domestic and industrial applications, such as environmental monitoring (monitoring ambient conditions, level of ammonia in stables), automotive (measure $\mathrm{NH}_{3}$ emission from vehicles), chemical industry (chemical leakage alarm), medical diagnostics (breath analysis), food safety, etc. ${ }^{7}$ Therefore, the design and manufacturing of an $\mathrm{NH}_{3}$ gas sensor has been demanded for process control and monitoring in laboratories, factories and public places.

There are many principles and methods described in literature for measuring ammonia. Besides conducting polymer gas detectors, ${ }^{8}$ catalytic sensors, ${ }^{9}$ spectrophotometric and other optical devices, ${ }^{10-11}$ chemiresistive-based sensors employing semiconducting metal oxides (MOX) as sensing layers were also widely used in the last decades. ${ }^{12}$ These types of sensors are typically operated at elevated temperature, usually more than $400{ }^{\circ} \mathrm{C}$. The major benefits of MOX-based sensors are their significant higher lifetime, increased robustness, ease of manufacturing, simplicity of measurement, low cost, and a wide detection range: from 1 to $1000 \mathrm{ppm}$. MOXbased sensors are by far the least expensive type of ammonia sensors and are not damaged or consumed by prolonged exposure to the analyte. However, because their output signal is non-linear, they need to be calibrated and adjusted for being reliably used in the desired detection range. ${ }^{13}$ Another drawback of MOX-based sensors is the significant cross-sensitivity, particularly with relative humidity.

A plethora of sensing layers based on MOX were tested for the $\mathrm{NH}_{3}$ detection, yielding different sensitivity, selectivity, and response time performance. Different mechanisms and models have been proposed to coherently explain the sensing capabilities of MOX.

In this paper, we introduce and use, for the first time to our knowledge, Pearson's Hard-Soft Acid-Base (HSAB) concept as a possible criterion to assess the sensitivity and selectivity of a number of MOX and of their nanocomposites as candidates to ammonia sensing.

To support the conjecture that the HSAB principle can be used when selecting the appropriate gas sensing layer (in particular for $\mathrm{NH}_{3}$ ), we will bring into the discussion facts and conclusions related to the following three issues:

1) the results obtained for the MOX based - trimethylamine sensing;

2) evaluation of fiber-optic ammonia sensor using MOX and their nanocomposites, showing that, despite a completely different detection principle, HSAB interpretation works and explains sensing mechanism;
3) changing the sensing paradigm and showing that, using the same principle, amino group - based molecules (polymers, carbon nanotubes, ionic liquids) can be evaluated as appropriate candidates for carbon dioxide detection.

\section{MOX-based Gas Sensing Layers Selection - General Theory}

Despite the measurement simplicity required by MOX-based gas sensors, their detection mechanism is complex and not yet fully understood. Electrophysical and chemical properties, catalytic activity, thermodynamic stability, adsorption ability, the adsorption/desorption properties of the surface (highly dependent on materials used and environmental parameters) are just a few of the MOX parameters which are responsible for the sensing mechanism. ${ }^{14-15}$ Beyond these aspects, it is obvious that recognition of the analyte through a gas-solid interface induces an electronic change of the metal oxide surface. ${ }^{16}$ One of the most used mechanism which explains ammonia sensing can be described by the reactions $1-7::^{17}$

$$
\begin{aligned}
& \mathrm{O}_{\text {2gas }} \leftrightarrow \mathrm{O}_{2 \text { ads }} \\
& \mathrm{O}_{2 \mathrm{ads}}+\mathrm{e}^{-} \leftrightarrow \mathrm{O}_{2 \mathrm{ads}}{ }^{-} \\
& \mathrm{O}_{2 \mathrm{ads}^{-}}+\mathrm{e}^{-} \leftrightarrow 2 \mathrm{O}_{\mathrm{ads}} \\
& \mathrm{O}_{\mathrm{ads}}{ }^{-}+\mathrm{e}^{-} \leftrightarrow \mathrm{O}_{\mathrm{ads}^{2-}}
\end{aligned}
$$

Once the MOX-based sensing layer is exposed to $\mathrm{NH}_{3}$, the reaction between the adsorbed oxygen ions and the $\mathrm{NH}_{3}$ molecules releases electrons in the MOX, leading to a thinner space-charge layer and a lower potential barrier. Consequently, the resistance of the MOX decreases. The process can be understood by using the following set of reactions $5-7:{ }^{18}$

$$
\begin{aligned}
& \mathrm{NH}_{3} \text { (gas) } \leftrightarrow \mathrm{NH}_{3} \text { (ads) } \\
& 2 \mathrm{NH}_{3} \text { (ads) }+3 \mathrm{O}_{\text {ads }}{ }^{-} \leftrightarrow \mathrm{N}_{2}+3 \mathrm{H}_{2} \mathrm{O}+3 \mathrm{e}^{-} \\
& 2 \mathrm{NH}_{3} \text { (ads) }+3 \mathrm{O}_{\text {ads }}{ }^{2-} \leftrightarrow \mathrm{N}_{2}+3 \mathrm{H}_{2} \mathrm{O}+6 \mathrm{e}^{-}
\end{aligned}
$$

Despite its reasonability (generation of electrons and decrease of MOX resistance, presence of adsorbed oxygen ions), this mechanism cannot explain the different sensing performances of different MOX-based layer. Why some MOX are more sensitive towards ammonia than others or why some MOX are selective and can discriminate between certain types of gases, but cannot discriminate between other types of gases, are some of the issues still unclear. 


\section{MOX-Based Gas Sensing Layers Selection - HSAB Theory}

We consider that direct and individual interaction of MOX metal cations and ammonia can have a cardinal importance in the sensing mechanism and in answering the questions listed above. For this purpose, we introduce and use Pearson's Hard-Soft Acid-Base (HSAB) theory.

The Hard-Soft Acid Base (HSAB) theory is a qualitative concept, developed by Ralph Pearson in the early 1960s, which justifies, among others, the propensity of some chemical species to interact with other species. ${ }^{19}$ The HSAB concept has proven to be a useful investigation tool in many areas of chemistry, such as: medicinal chemistry, toxicology, ${ }^{20}$ quantum dot functionalization and design of quantum dot solar cells, ${ }^{21} \mathrm{TiO}_{2}$ functionalization, ${ }^{22}$ computational chemistry, ${ }^{23}$ design and synthesis of sensing layers employed in nano - resonators based $\mathrm{CO}_{2}$ detection, ${ }^{24-25}$ design of sensing layer for sulfur dioxide detection, ${ }^{26}$ ethanol gas sensing, ${ }^{27}$ glucose electrochemical sensing, ${ }^{28} \mathrm{NO}_{2}$ gas sensing, ${ }^{29}$ corrosion, ${ }^{30}$ adsorption phenomena. $^{31}$

The HSAB principle operates with Lewis bases and acids; a molecule donating a pair of electrons is classified as a base, while a molecule accepting a pair of electrons it is classified as an acid. Pearson divides Lewis' bases and acids into hard, borderline, and soft. Hard bases tend to have low ionic radii, high HOMO energy level, while hard acids have empty orbitals in their valence shells, high positive charge and high LUMO energy level. At the same time, soft acids exhibit large ionic radii, while soft bases have large atoms with high polarizability. ${ }^{32}$ Borderline species have an intermediate character between hard and soft species. It is worth pointing out that, to be classified as soft, hard or borderline, a Lewis base or acid doesn't have to possess all the above-mentioned properties.

Examples of hard, soft and borderline acids and bases are given in Table 1. The large electronegativity differences between hard acids and hard bases lead to strong ionic interactions, while the electronegativities of soft acids and soft bases are almost the same, hence their interactions are predominantly covalent. ${ }^{33}$ According to the HSAB theory, a hard base prefers to interact to a hard acid, a soft base prefers to interact to a soft acid, while a borderline base tends to bond to borderline acid.

Recently, a new concept, inverse Hard Soft Acid Bases (IHSAB), was introduced and employed for selecting and synthesizing gas sensing materials. ${ }^{34-35}$ This concept, based on the reversible interaction of hard-acid surfaces with soft bases and hard-base surfaces with soft acids, relies, as dominant adsorption process, on physisorption. This is a major difference from the HSAB concept, which mainly operates with the chemisorption phenomenon. Actually, the IHSAB principle introduces the concept of electron transduction, which is defined as the transfer of electrons to or from an interface without the formation of a chemical bond. ${ }^{36}$

From the HSAB theory perspective, ammonia is classified as hard base (in bold in Table 1). Thus, according to the HSAB principle, hard acid species (with asterisk in Table 1) are feasible candidates for ammonia detection. Indeed, by investigating the literature, we found that most of the MOX exhibiting good performances (in terms of sensitivity, selectivity, recovery time, etc.) to ammonia detection are classified as hard acids according to HSAB theory. Six such cases are described and briefly analyzed below.

\section{MOX-Based Sensing Layers for Ammonia Chemiresistive Detection}

\section{1. The Sensing Layer is Based on One MOX with Cations Classified as Hard Acid}

$\mathrm{TiO}_{2}, \mathrm{In}_{2} \mathrm{O}_{3}, \mathrm{ZrO}_{2}, \beta-\mathrm{Ga}_{2} \mathrm{O}_{3}, \alpha-\mathrm{Fe}_{2} \mathrm{O}_{3}, \mathrm{SnO}_{2}$, which are MOX having hard acid cations, were used as sensing layer in chemiresistive sensors for ammonia (gas and aqueous) detection.

Table 1. Examples of hard, soft and borderline acids and bases

\begin{tabular}{|c|c|c|c|}
\hline & Soft & Borderline & Hard \\
\hline Bases & $\begin{array}{c}\mathrm{SCN}^{-}, \mathrm{C}_{2} \mathrm{H}_{4} \\
\mathrm{RSH}, \mathrm{CO}, \mathrm{R}_{3} \mathrm{P} \\
\mathrm{R}_{3} \mathrm{As},(\mathrm{RO})_{3} \mathrm{P} \\
\mathrm{CN}^{-} \\
\mathrm{RCN}, \mathrm{R}_{3} \mathrm{P}, \mathrm{C}_{6} \mathrm{H}_{6} \mathrm{I}^{-}\end{array}$ & $\begin{array}{c}\text { Aniline }\left(\mathrm{C}_{6} \mathrm{H}_{5}-\mathrm{NH}_{2}\right) \\
\mathrm{C}_{5} \mathrm{H}_{5} \mathrm{~N} \text { (pyridine) } \\
\mathrm{N}_{2}, \mathrm{Br}^{-}, \mathrm{N}_{3}^{-}\end{array}$ & $\begin{array}{c}\mathrm{PO}_{4}{ }^{3-}, \mathrm{CH}_{3} \mathrm{OH}, \mathrm{C}_{2} \mathrm{H}_{5} \mathrm{OH}, \mathrm{C}_{2} \mathrm{H}_{5} \mathrm{O}^{-} \\
\mathrm{HO}^{-}, \mathrm{ClO}_{4}^{-}, \mathrm{N}_{2} \mathrm{H}_{4}, \mathrm{CH}_{3} \mathrm{COO}^{-} \\
\mathrm{NH}_{3}{ }^{*} \\
\mathrm{Me}-\mathrm{NH}_{2}, \mathrm{Me}_{2} \mathrm{NH}, \mathrm{Me}_{3} \mathrm{~N}, \mathrm{H}_{2} \mathrm{~N}- \\
\left(\mathrm{CH}_{2}\right)_{4}-\mathrm{NH}_{2}, \mathrm{H}_{2} \mathrm{~N}-\left(\mathrm{CH}_{2}\right)_{5}-\mathrm{NH}_{2} \\
\mathrm{H}_{2} \mathrm{O}, \mathrm{CO}_{3}{ }^{2-}, \mathrm{Cl}^{-}\end{array}$ \\
\hline Acids & $\begin{array}{c}\mathrm{Pt}^{2+} \\
\mathrm{Cu}^{+}, \mathrm{Au}^{+} \mathrm{Ag}^{+}, \mathrm{Pd}^{2+} \\
\text { Metal atoms in zero oxidation state }\end{array}$ & $\begin{array}{l}\mathrm{Fe}^{2+}, \mathrm{Bi}^{3+}, \mathrm{Ni}^{2+} \\
\mathrm{Zn}^{2+}, \mathrm{B}\left(\mathrm{CH}_{3}\right)_{3} \\
\mathrm{~Pb}^{2+}, \mathrm{NO}^{+}, \mathrm{Cu}^{2+}\end{array}$ & $\begin{array}{c}\mathrm{CO}_{2}, \mathrm{Sm}^{3+^{*}}, \mathrm{Ga}^{3+^{*}} \\
\mathrm{In}^{3+^{*}}, \mathrm{BeMe}_{2} \\
\mathrm{Gd}^{3+^{*}}, \mathrm{Li}^{+}, \mathrm{B}(\mathrm{OR})_{3}, \mathrm{Mg}^{2+}, \mathrm{Al}^{3+} \\
\mathrm{BF}_{3}, \mathrm{Fe}^{3+^{*}}, \mathrm{Co}^{3+^{*}}, \mathrm{BCl}_{3}, \mathrm{Ti}^{4+^{*}} \\
\mathrm{La}^{3+^{*}}, \mathrm{Cr}^{3+^{*}}, \mathrm{Zr}^{4+^{*}}, \mathrm{AlMe}_{3}\end{array}$ \\
\hline
\end{tabular}


Karuganaran et al. developed a $\mathrm{NH}_{3}$ planar structure sensor employing a $\mathrm{TiO}_{2}$ film deposited by a direct current (DC) reactive magnetron sputtering technique onto a silicon substrate having interdigitated comb shaped electrodes. ${ }^{37}$ Appropriate annealing temperature of the film formation was found to be $873 \mathrm{~K}$, while an operating temperature at $250{ }^{\circ} \mathrm{C}$ ensured highest sensitivity to the detection of the $\mathrm{NH}_{3}$ gas.

$\mathrm{Li}$ et al. used single-crystalline $\operatorname{In}_{2} \mathrm{O}_{3}$ nanowires for $\mathrm{NH}_{3}$ detection at room temperature. Ammonia sensing layer based on $\mathrm{In}_{2} \mathrm{O}_{3}$ nanowires exhibited "on/off" ratios (i.e., the ratio between the measured currents during and before the $\mathrm{NH}_{3}$ exposure) around 50 and response times around $20 \mathrm{~s}$, with ambient air initialization for $1 \% \mathrm{NH}_{3}{ }^{38}$ It has also been found that oxygen has a relatively minor effect on the nanowire conductance. The authors explained the sensing mechanism based on the electrons transfer from the adsorbed $\mathrm{NH}_{3}$ molecules into the $\mathrm{In}_{2} \mathrm{O}_{3}$ nanowire, explanation which agrees with the HSAB theory, as $\mathrm{In}^{3+}$ is classified as hard acid, while ammonia molecule is hard base.

Deshmukh et al. reported on the development of an ammonia sensor using $\mathrm{ZrO}_{2}$ thin film as sensing layer. The film was prepared using the spray pyrolysis technique. ${ }^{39}$ The sensor showed quick response (4s) and fast recovery (10 s).

Pandeeswari et al. used nanocrystallite $\beta-\mathrm{Ga}_{2} \mathrm{O}_{3}$ thin films for ammonia sensing at $30^{\circ} \mathrm{C} .{ }^{40} \mathrm{In}$ this case, the lowest detection limit of ammonia was found to be $0.5 \mathrm{ppm}$. The response and recovery times were $40 \mathrm{~s}$ and $18 \mathrm{~s}$, respectively (for a $0.5 \mathrm{ppm} \mathrm{NH}_{3}$ level). The authors demonstrated that the nanocrystallite $\beta-\mathrm{Ga}_{2} \mathrm{O}_{3}$ thin film has a comparatively lower sensitivity for toluene, xylene, formaldehyde and acetone than for ammonia. This result agrees with the HSAB theory. None of the other measurands is a hard base, so it is reasonable to explain the preference of $\mathrm{Ga}^{3+}$ - a hard acid and part of the sensing layer - for ammonia (hard base).

Abaker et al. reported on the utilization of $\alpha-\mathrm{Fe}_{2} \mathrm{O}_{3}$ nanoellipsoids thin films for developing a highly sensitive chemical sensor for aqueous ammonia. ${ }^{41}$ The device exhibited a very high and reproducible sensitivity of $\sim 4.678 \mu \mathrm{A} \mathrm{cm}^{-2} \mathrm{mM}^{-1}$, a detection limit of $\sim 0.04 \mathrm{nM}$ and a short response time (10.0 s).

By far, $\mathrm{SnO}_{2}$ is the most widely used MOX for ammonia detection. Rout et al. investigated ammonia sensing characteristics of $\mathrm{SnO}_{2}$ nanoparticles over a wide range of concentrations (1-800 ppm) and temperatures (100-300 $\left.{ }^{\circ} \mathrm{C}\right) .{ }^{42} \mathrm{No}$ interference with $\mathrm{NH}_{3}$ detection was found from $\mathrm{H}_{2}$, CO, nitrogen oxides, $\mathrm{H}_{2} \mathrm{~S}$ and $\mathrm{SO}_{2}$. Experimental results described in literature revealed that the $\mathrm{SnO}_{2}$-based gas sensors exhibit linear dependence between the logarithm of the gas sensitivity and logarithm of the sample concentration when detecting both ammonia and methanol, at an operating temperature of $350{ }^{\circ} \mathrm{C}^{43} \mathrm{SnO}_{2}$ shows high sensitivity towards both ammonia and other hard bases (such as methanol, for instance), but cannot discriminate between. This, again, is in good agreement with the HSAB theory.

\section{2. The Sensing Layer Comprises 2 Types of MOXs, One of them Acting as Promoter}

Both MOX contain cations classified as hard acid.

Wang et al. demonstrated that hybrid $\mathrm{Co}_{3} \mathrm{O}_{4} / \mathrm{SnO}_{2}$ core-shell nanospheres can be used as sensing layer for real-time, rapid-response, ammonia gas sensors. ${ }^{44}$ The core - shell architecture enabled improved flexibility of the gas sensor surface compared to commonly used sensing layers. Cations of both metal oxides semiconducting are hard acids.

\section{3. The Sensing Layer Comprises 2 Types of MOXs, One of them Acting as Promoter}

Only the cations of the promoter are classified as hard acid.

$\mathrm{Cr}_{2} \mathrm{O}_{3}$-activated $\mathrm{ZnO}$ and zinc oxide thin film doped with $\mathrm{Al}_{2} \mathrm{O}_{3}, \mathrm{TiO}_{2}$ are examples for this category. ${ }^{45-46}$ Here, the promoter enhances the sensitivity of the sensing layer towards ammonia and trimethylamine molecules. It is important to emphasize that pure $\mathrm{ZnO}$ thick films $\left(\mathrm{Zn}^{2+}\right.$ being a bordeline acid, according to HSAB theory), prepared by screen-printing technique, is almost insensitive to $\mathrm{NH}_{3}$. However, when pure $\mathrm{ZnO}$ thick films - for which the surface was activated with $\mathrm{Cr}^{3+}$ (a hard acid) - were measured, experimental results demonstrated that the structure is sensitive and highly selective to $300 \mathrm{ppm}$ of $\mathrm{NH}_{3}$ gas, at room temperature. The changed sensitivity could be attributed to the presence of hard acid species (i. e., $\mathrm{Cr}^{3+}$ cations).

\section{4. The Sensing Layer is a Nanostructured Composite Material, Comprising:}

a. One semiconducting metal oxide whose cations are classified as hard acid and

\section{b. A carbonic material}

Examples include $\mathrm{SnO}_{2} /$ MWCNTs composite, ${ }^{47}$ porous indium oxide nanotubes/carbon nanotubes, $\mathrm{Fe}_{2} \mathrm{O}_{3} /$ carbon nanotubes. All these nanocomposites were used for selective ammonia gas sensing.

\section{5. The Sensing Layer is a Nanostructured Composite Material Consisting of:}

a. One semiconducting metal oxide whose cations are classified as hard acid and

\section{b. Another semiconducting material}

Examples include $p$-toluenesulfonic acid doped polyaniline-titanium dioxide, $\mathrm{SnO}_{2}-\mathrm{SnS}_{2}$ nanocomposite, 
$\mathrm{TiO}_{2}$-PANI (polyaniline) / PA6 (polyamide 6) composite nanofibers. All these nanocomposites were used for highly sensitive ammonia gas sensing. ${ }^{48}$

\section{6. The Sensing Layer Contains Two Types of Semiconducting Metal Oxides, but Only the Core Metal Oxide's Cations are Classified as Hard Acid}

A good example in this category is the $\mathrm{NiO}$-wrapped mesoporous $\mathrm{TiO}_{2}$ microspheres. In comparison with pure $\mathrm{TiO}_{2}$, the sensor using $10 \mathrm{wt} \% \mathrm{NiO}$-wrapped mesoporous $\mathrm{TiO}_{2}$ composite microspheres as sensing layer, exhibits no response to other volatile organic compounds (VOCs) and an excellent selectivity to detect ammonia in humid air with UV illumination at room temperature. ${ }^{49}$

All the examples presented above demonstrate that, at least in the first stage, the interaction between the analyte (ammonia and aliphatic amines) and MOX acting as sensing layer, can be analyzed and interpreted in terms of the HSAB theory.

\section{MOX-Based Sensing Layers for Chemiresistive Detection of Other Hard Base Gases}

Besides ammonia, there are a several other amino groups based compounds which are categorized as hard bases, in accordance to the HSAB theory. Among these, one can mention methylamine, dimethylamine and biogenic amines, such as trimethylamine, cadaverine, and putresceine. Biogenic amines are degradation products found in spoiled meat products and are a good indicator for bacterial contamination. Trimethylamine is a suitable target for the detection of biogenic amines due to its volatility. ${ }^{50}$

A significant effort has been devoted to design suitable sensing layers for trimethylamine monitoring. A question arises: if trimethylamine is classified as hard base (like ammonia), is it possible to use the same type of reasoning when selecting MOX - based trimethylamine sensing layers as that employed for designing ammonia sensing layers? Reviewing the literature data, it can be indeed demonstrated that most of the MOXs (either simple or composite, with different thickness, morphologies and structural architectures) used with promising results in trimethylamine sensing, do contain species which can be classified as hard acids and that can be used, also, for ammonia sensing. Branch-like hierarchical heterostructure $\left(\alpha-\mathrm{Fe}_{2} \mathrm{O}_{3} / \mathrm{TiO}_{2}\right.$ ), $\mathrm{TiO}_{2}, \mathrm{ZnO}-\mathrm{In}_{2} \mathrm{O}_{3}$ composite nanofibers, $\mathrm{ZnO}-\mathrm{Cr}_{2} \mathrm{O}_{3}$ hetero-nanostructures are just a few examples supporting the idea that HSAB interaction could play an important role in trimethylamine sensing mechanism. ${ }^{51-55}$

\section{MOX-Based Sensing Layers for Ammonia Optical Detection}

MOXs can be used, as sensing element, in the detection and monitoring of ammonia in devices employing fiber - optics technics. Examples of fiber optical sensors showing good ammonia detection capabilities include $\mathrm{Gd}_{2} \mathrm{O}_{3}$ nanorods (with thickness ranging from 80 to $120 \mathrm{~nm}$ ), thin films based on $\mathrm{Ag} / \mathrm{SnO}_{2}$ and nanocrystalline $\mathrm{SnO}_{2} \cdot{ }^{56-58}$ All these MOXs contain hard acid species. For fiber optic ammonia sensor, the sensing mechanism is completely different than the one specific to chemiresistive sensors. Here, the sensing principle relies on the change of the MOX refractive index upon its reaction with $\mathrm{NH}_{3}$. So, it is reasonable to consider that the interaction between MOXs cations and ammonia - following the HSAB related rules - drives the sensing.

\section{HSAB Theory Employed as a Sensing Layer Selection Tool}

Since the HSAB theory proves to be highly applicable in choosing sensing layer and has virtually general validity (i.e., not being limited to a certain sensing principle), one can anticipate that the roles of the hard acid - hard base tandem can be interchanged. It is reasonable to rationalize that, if ammonia (a hard base) can be sensed using MOXs containing hard acids cations, then amino group-based molecules, which are formally derivatives of ammonia, can be used as sensing layers for any type of gas classified as hard acid. Indeed, $\mathrm{CO}_{2}$ (a hard acid) sensing can be performed with amino group - based molecules, such as polymers, carbon nanotubes, ionic liquids and their matrix nanocomposites, thus confirming the interaction predicted by the HSAB theory. Among these, one can enumerate $\mathrm{CO}_{2}$ sensing layers based on polyallylamine, polyallylamine-amino carbon nanotubes (CNTs) matrix nanocomposite, polyethyleneimine-amino CNTs matrix nanocomposite. ${ }^{24,59-60}$ All these types of $\mathrm{CO}_{2}$ sensing layers were used on Surface Acoustic Waves (SAW) devices, employing quartz as a piezoelectric substrate, as depicted in Figure 1.

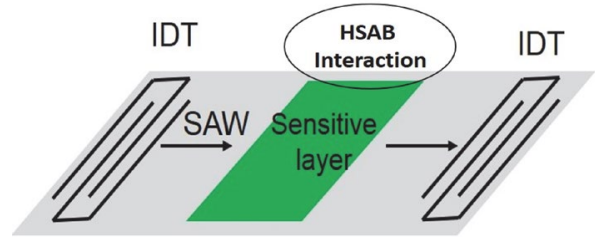

Figure 1. The structure of SAW device.

The HSAB interaction of $\mathrm{CO}_{2}$ with the above-mentioned amino group-based molecules is reversible, yielding to carbamates. A well-known example is the reaction of $\mathrm{CO}_{2}$ with polyallylamine (PAA), shown in Scheme 1. 


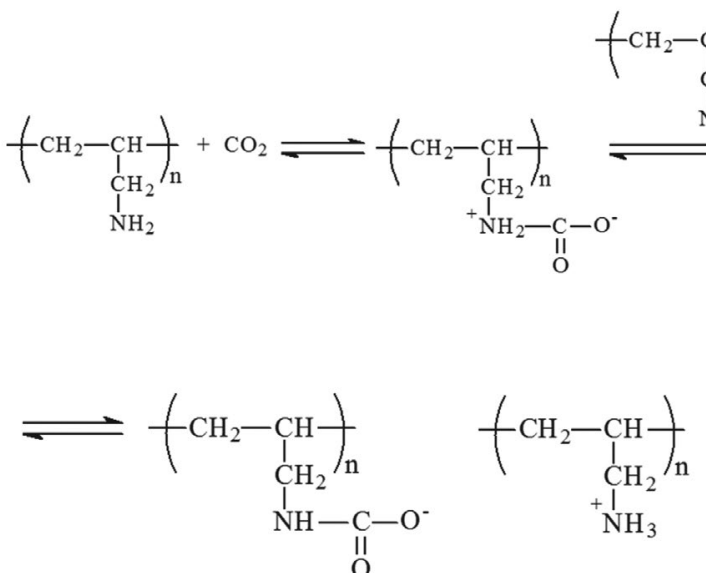

Scheme 1. Reaction of PAA with $\mathrm{CO}_{2}$.

Furthermore, a convincing semiquantitative demonstration of the validity of $\mathrm{HSAB}$ principle in SAW $\mathrm{CO}_{2}$ sensing with amino groups based compounds, comes from comparing the frequency shifts (at $2500 \mathrm{ppm}$ of $\mathrm{CO}_{2}$ exposure), for the three sensing layers: polyallylamine (PAA), polyallylamine - amino carbon nanotubes (aCNTs, shown in Figure 2) and polyethyleneimine (PEI) - aminocarbon nanotubes. As depicted in Figure 3, better results (in terms of sensitivity) are obtained when using as sensing layers simple polymers (PAA) rather than matrix nanocomposites (polyallylamine-amino CNTs and polyethyleneimine-amino CNTs), respectively. The most resonable explanation for these results is related to the type of amino groups at the surface of the carbon nanotubes. According to $\mathrm{HSAB}$, primary amino groups grafted on the CNT are categorized as borderline bases, and their affinity for $\mathrm{CO}_{2}$ molecules is lower in comparison with that exhibited by the aliphatic amino groups which exist in PEI and PAA.

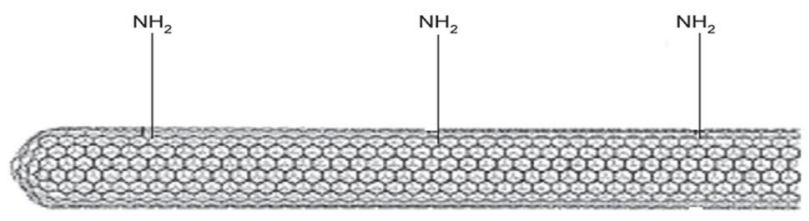

Figure 2. The structure of amino carbon nanotubes.

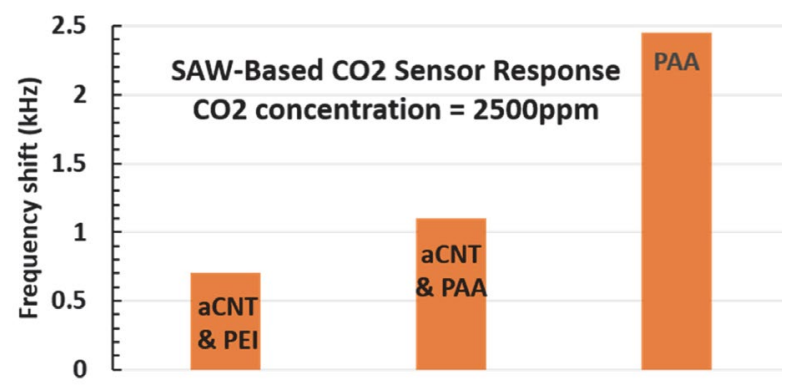

Figure 3. Frequency shifts at $2500 \mathrm{ppm} \mathrm{CO}_{2}$ concentration for different sensing layers used to coat SAW devices.
For this reason, both PAA-amino CNTs and PEI-amino CNTs nanocomposites show lower sensitivity than simple polymers. ${ }^{61-64}$

The HSAB principle - based approach can work only if there is a direct interaction between ammonia (amine) and metal oxides surface. If the surface of the metal oxide semiconducting is covered with other molecules, a different type of sensing mechanism should be considered. For instance, if $\mathrm{TiO}_{2}$ is sensitized with different anthocyanin pigments, the following reactions are responsible for the changing resistance of the $\mathrm{TiO}_{2}$ :

$$
\begin{aligned}
& \text { Pigment }+\mathrm{RNH}_{2}(\mathrm{~g}) \leftrightarrow \text { Pigment }^{-}+\mathrm{RNH}_{3}^{+} \\
& \text {Pigment }+\mathrm{H}_{2} \mathrm{O}(\mathrm{g}) \leftrightarrow \text { Pigment }^{-}+\mathrm{H}_{3} \mathrm{O}^{+} \\
& \mathrm{RNH}_{2}(\mathrm{~g})+\mathrm{H}_{3} \mathrm{O}^{+} \leftrightarrow \mathrm{RNH}_{3}^{+}+\mathrm{H}_{2} \mathrm{O}(\mathrm{g})
\end{aligned}
$$

In (10), R stands for $\mathrm{H}$ and $\mathrm{Me}$. As it can be observed, there is a proton exchange (in this case we can discuss about Bronsted - Lowry acid and bases) and the presence of adsorbed water is a sine qua non condition for dissolving and diffusing the analyte into the interfacial region. ${ }^{65}$

\section{Conclusions}

The paper introduces the Hard-Soft Acid Base (HSAB) theory as a valuable tool for the selection of MOX - based sensing layers for ammonia and aliphatic amines detection. Six case studies of ammonia detection by means of chemiresistive sensors employing MOXs - based sensing layers were discussed in the view of this concept. To further support the suitability of the HSAB concept in selecting sensing layers, an example of a fiber-optic ammonia sensor using MOX and their nanocomposites as sensing layer was found to also fit HSAB interpretation. Within the same HSAB framework, we demonstrate that the same MOXs (hard acids) employed as sensing layer for $\mathrm{NH}_{3}$ detection, can be used for trimethylamine detection, given that both $\mathrm{NH}_{3}$ and trimethylamine are hard bases. By changing the sensing paradigm, the paper shows that, by applying the HSAB principle, amino groups-based molecules (formally derivatives of ammonia, thus, hard bases), such as polymers, carbon nanotubes and ionic liquids, are appropriate sensing layers for $\mathrm{CO}_{2}$ (hard acid) detection.

Obviously, the $\mathrm{NH}_{3}-\mathrm{MOX}$ interaction is not the only factor influencing the overall performance of the sensor. Aspects such as morphology and thickness of the sensing layer, deposition method, presence of promotors, temperature, humidity, do influence the sensing process. At the same time, more refined calculus in terms of electronegativity, HOMO and LUMO energy levels and local hardness are necessary for better understanding key sensing properties of MOXs and their nanocomposites towards $\mathrm{NH}_{3}$ and related molecules. 


\section{References}

1. Good for Gas Instrumentation, https://goodforgas.com/ (assessed: June 11, 2018).

2. National Research Council, Acute exposure guideline levels for selected airborne chemicals, The National Academies Press, USA, 2010.

3. R. E. De la Hoz, D. P. Schuetter, W. N. Rom, Am. J. Ind. Med., 1996, 29(2), 209-214.

DOI:10.1002/(SICI)1097-0274(199602)29:2<209:

:AID-AJIM12>3.0.CO;2-7

4. R. A. Michaels, Environ. Health Perspect., 1999, 107 (8), 617627. DOI:10.1289/ehp.99107617

5. L. Pauling, General chemistry, Courier Corporation, North Chelmsford, USA, 1988.

6. R. Chang, J. Overby, General chemistry: the essential concepts, Mc Graw Hill, New York, USA, 2000.

7. B. Timmer, W. Olthuis, A. Van Den Berg, Sens. Actuators B, 2005, 107(2), 666-677. DOI:10.1016/j.snb.2004.11.054

8. R. Blair, H. Sheperd, T. Faltens, P. C. Haussmann, R. B. Kaner, S. H. Tolbert, B. H. Weiller, J. Chem. Educ., 2008, 85(8), 1102-1104. DOI:10.1016/j.snb.2004.11.054

9. F. Winquist, A. Spetz, I. Lundstrom, Anal. Chim. Acta, 1984, 164, 127-138. DOI:10.1016/S0003-2670(00)85624-X

10. A. Elamari, N. Gisin, J. L. Munoz, S. Poitry, M. Tsacopoulos, H. Zbinden, Sens. Actuators B, 1997, 38/39, 183-188. DOI:10.1016/S0925-4005(97)80190-6

11. G. H. Mount, B. Rumberg, J. Havig, B. Lamb, H. Westberg, D. Yonge, K. Johson, R. Kincaid, Atmos. Environ., 2002, 36 (11), 1799-1810. DOI:10.1016/S1352-2310(02)00158-9

12. S. Jain, A. Patrike, S. S. Badadhe, M. Bhardwaj, S. Ogale, ACS Omega, 2018, 3(2), 1977-1982.

13. C. N. Xu, N. Miura, Y. Ishida, K. Matuda, N. Yamazoe, Sens. Actuators B, 2000, 65, 163-165.

DOI:10.1016/S0925-4005(99)00413-X

14. D. Williams, Sens. Actuators B, 1999, 57, 1-16.

DOI:10.1016/S0925-4005(99)00133-1

15. S. R. Morrison, Sens. Actuators B, 1987, 11, 283-287. DOI:10.1016/0250-6874(87)80007-0

16. S. M. Kanan, O. M. El-Kadri, I. A. Abu-Yousef, M. C. Kanan, Sensors, 2009, 9(10), 8158-8196. DOI:10.3390/s91008158

17. X. Wang, H. Quin, Y. Chen, J. Hu, J. Phys. Chem. C, 2014, 118, 28548-28561. DOI:10.1021/jp501880r

18. X. Liu, N. Chen, B. Han, X. Xiao, G. Chen, I. Djerdj, Y. Wang, Nanoscale, 2015, 7(36), 14872-14880.

DOI:10.1039/C5NR03585F

19. R. G. Pearson, J. Am. Chem. Soc., 1963, 85, 3533-3539. DOI:10.1021/ja00905a001

20. R. M. Lopachin, T. Gavin, A. Decaprio, D. S. Barber, Chem. Res. Toxicol., 2012, 25, 239-251. DOI:10.1021/tx2003257

21. B. C. Serban, M. N. Mihaila, V. G. Dumitru, C. Bostan, S. D. Costea, Quantum dot solar cell, US Patent Number 8,299,355 B2, date of patent October 30, 2012.

22. B. C. Serban, M. N. Mihaila, V. G. Dumitru, C. Bostan, S. D. Costea, M. Bercu, Quantum dot solar cell, US Patent Number 8,148,632 B2, date of patent April 3, 2012.
23. F. R. Ramos-Morales, S. Durand-Niconoff, J. Correa-Basurto, F. J. Meléndez-Bustamante, J. S. Cruz-Sánchez, J. Mex. Chem. Soc., 2008, 52(4), 241-248.

24. B. C. Serban, A. K. Sarin-Kumar, S. Costea, M. Mihaila, O. Buiu, M. Brezeanu, N. Varachiu, C. Cobianu, Romanian Journal of Inf. Sci. \& Tech., 2009, 12(3), 376-384.

25. B. C. Serban, M. Mihaila, C. Cobianu, V. G. Dumitru, O. Buiu, Carbon dioxide sensor, US Patent Number 8,826,724 B2, date of patent September 9, 2014.

26. B. C. Serban, C. Cobianu M.N. Mihaila, V.-G. Dumitru, US Patent Number 8,230,720 B2, date of patent July 31, 2012.

27. B. C. Serban, O. Buiu, M. Brezeanu, O. Ionescu, C. Cobianu, Romanian Journal of Inf. Sci. \& Tech, 2018, 21(1), 93-96.

28. J. Nai, S. Wang, Y. Bai, L. Guo, Small, 2013, 9(18), 3147-3152. DOI:10.1002/smll.201203076

29. B. C. Serban, C. Cobianu, M. Mihaila, V.-G. Dumitru, O. Buiu, US Patent Number 8,563,319 B2, date of patent October 22, 2013.

30. F. H. Walters, J. Chem. Educ., 1991, 68 (1), 29-31. DOI:10.1021/ed068p29

31. A. Alfarra, E. Frackowiak, F. Beguin, Appl. Surf. Sci., 2004, 228 (1-4), 84-92. DOI:10.1016/j.apsusc.2003.12.033

32. R. G. Pearson, Inorg. Chem., 1988, 27(4), 734-740. DOI:10.1021/ic00277a030

33. R. G. Pearson, Inorg. Chim. Acta, 1995, 240(1-2), 93-98. DOI:10.1016/0020-1693(95)04648-8

34. J. L. Gole, S. Ozdemir, ChemPhysChem, 2010, 11(12), 25732581. DOI: $10.1002 /$ cphc. 201000245

35. J. L. Gole, Gas sensors, methods of preparation thereof, methods of selecting gas sensor materials, and methods of use of gas sensors, U.S. Patent Number 8,573,030 B2, date of patent November 5, 2013.

36. W. I. Laminack, J. L. Gole, Nanomaterials, 2013, 3(3), 469485. DOI:10.3390/nano3030469

37. B. Karuganaran, P. Uthirakumar, S. J. Chung, S. Velumani, E. K. Suh, Mater. Charact., 2007, 58(8-9), 680-684. DOI:10.1016/j.matchar.2006.11.007

38. C. Li, D. Zhang, B. Lei, S. Han, X. Liu, C. Zhou, J. Phys. Chem. $B$, 2003, 107(45), 12451-12455. DOI:10.1021/jp0361531

39. S. B. Deshmukh, R. H. Bari, Intl. Lett. Chem., Phys. Astron., 2015, 56, 144-154.

40. R. Pandeeswari, B. G. Jeyaprakash, Sens. Actuators B, 2014, 195, 206-214. DOI:10.1016/j.snb.2014.01.025

41. M. Abaker, A. Umar, S. Baskoutas, G. N. Dar, S. Zaidi, A. Al-Sayari, S. H. Kim, S. W. Hwang, J. of Phys. D: Appl. Phys., 2011, 44(42), 425401-425404.

DOI:10.1088/0022-3727/44/42/425401

42. C. S. Rout, M. Hegde, A. Govindaraj, C. N. R. Rao, Nanotechnology, 2007, 18(20), 205504-205508.

DOI:10.1088/0957-4484/18/20/205504

43. A. Teeramongkonrasmee, M. Sriyudthsak, Sens. Actuators B, 2000, 66(1-3), 256-259.

DOI:10.1016/S0925-4005(00)00346-4

44. L. Wang, Z. Lou, R. Zhang, T. Zhou, J. Deng, T. Zhang, ACS Appl. Mat. Interfaces, 2016, 8(10), 6539-6545.

DOI:10.1021/acsami.6b00305 
45. D. R. Patil, L. A. Patil, P. P. Patil, Sens. Actuators B, 2007, 126(2), 368-374. DOI:10.1016/j.snb.2007.03.028

46. S. H. Park, J. Y. Ryu, H. H. Choi, T. H. Kwon, Sens. Actuators $B, 1998,46(2), 75-79$.

DOI:10.1016/S0925-4005(97)00324-9

47. N. Va Hieu, L. T. B. Thuy, N. D. Chien, Sens. Actuators B, 2008, 129(2), 888-895. DOI:10.1016/j.snb.2007.09.088

48. M. O. Ansari, F. Mohammad, Sens. Actuators B, 2011, 157(1), 122-129. DOI:10.1016/j.snb.2011.03.036

49. X. Li, N. Chen, S. Lin, J. Wang, J. Zhang, Sens. Actuators $B$, 2015, 209, 729-734. DOI:10.1016/j.snb.2014.12.031

50. G. Falony, S. Vieira-Silva, J. Raes, Annu. Rev. Microbiol., 2015, 69, 305-321. DOI:10.1146/annurev-micro-091014-104422

51. Z. Lou, F. Li, J. Deng, L. Wang, T. Zhang, ACS Appl. Mater. Interfaces, 2013, 5(23), 12310-12316.

DOI:10.1021/am402532v

52. Y. Takao, Y. Iwanaga, Y. Shimizu, M. Egashira, Sens. Actuators B, 1993, 10(3), 229-234. DOI:10.1016/0925-4005(93)87011-D

53. P. M. Perillo, D. F. Rodriguez, J.Alloys and Compd., 2016, 657, 765-769. DOI:10.1016/j.jallcom.2015.10.167

54. C. S. Lee, I. D. Kim, J. H. Lee, Sens. Actuators B, 2013, 181, 463-470. DOI:0.1016/j.snb.2013.02.008

55. H. S. Woo, C. W. Na, I. D. Kim, J. H. Lee, Nanotechnology, 2012, 23(24), 245501-245504.

DOI:10.1088/0957-4484/23/24/245501

56. J. S. Kumar, B. Ranghanatawwwn, D. Sastikumar, in: AIP Conference Proceedings Vol. 1832 (1), 2017, 050119.

57. A. Pathak, S. K. Mishra, B. D. Gupta, Appl. Opt., 2015, 54(29), 8712-8721. DOI:10.1364/AO.54.008712
58. B. Renganathan, G. Gobi, D. Sastikumar, R. Srinivasan, A. C. Bose, Sens. Lett., 2010, 8(2), 292-296.

DOI:10.1166/sl.2010.1266

59. B. C. Serban, M. Brezeanu, C. Cobianu, S. Costea, O. Buiu, A. Stratulat. N. Varachiu, Materials selection for gas sensing. An HSAB perspective, in: Proc. IEE International Semiconductor Conference (CAS), 2014, pp. 21-30.

60. V. Avramescu, C. Bostan, B. C. Serban, I. Georgescu, S. Costea, N. Varachiu, C. Cobianu, in: Proc. IEEE International Semiconductor Conference (CAS), 2009, 27-36.

61. B. C. Serban, A.K. Sarin Kumar, M. Brezeanu, C. Cobianu, O. Buiu, C. Bostan, N. Varachiu, S. Costea, in: Proc. IEEE International Semiconductor Conference (CAS), 2011, 127-130.

62. B. C. Serban, A. K. Sarin Kumar, M. Brezeanu, C. Cobianu, O. Buiu, C. Bostan, N. Varachiu, S. Costea, Romanian Journal of Inf. Sci. \& Tech, 2011, 14(3), 222-231.

63. B. C. Serban, C. Cobianu, M. Bercu, N. Varachiu, M. N. Mihaila, C. G. Bostan, S. I. Voicu, Matrix nanocomposite containing amino carbon nanotubes for carbon dioxide sensor detection, US Patent Number 7,913,541 B2, date of patent March 31, 2011.

64. B. C. Serban, C. Cobianu, M.N. Mihaila, V.-G. Dumitru, Functionalized monolayers for carbon dioxide detection by a resonant nanosensor, US Patent Number 8,230,720 B2, date of patent July 31, 2012.

65. L. Yanxiao, Z. Xiao-Bo, H. Xiao-Wei, S. Ji-Yong, Z. Jie-Wen, M. Holmes, L. Hao. Biosens. Bioelectron., 2015, 67, 35-41 DOI:10.1016/j.bios.2014.05.040

\section{Povzetek}

V prispevku je prikazano, kako lahko uporabimo teorijo trdih in mehkih kislin in baz (Hard-Soft Acid base (HSAB)) kot koristen kriterij pri izbiri polprevodnih kovinskih oksidov, primernih za pripravo senzorskih plasti za detekcijo amonijaka. Preučili smo šest različnih primerov detekcije amonijaka, pri katerih uporabljajo senzorje na osnovi kovinskih oksidov in sorodnih nanokompozitov. Vlogo teorije HSAB, kot učinkovitega izbirnega orodja za ustrezno senzorsko plast, primerno za kakršnokoli vrsto plina, smo dodatno raziskali z analizo literaturnih podatkov trimetilaminskih senzorskih plasti na osnovi kovinskih oksidov. Z analizo delovanja senzorja iz optičnih vlaken za detekcijo amonijaka dokazujemo, da se lahko HSAB princip uspešno uporabi tudi pri izbiri senzorskih plasti za detektorje, ki uporabljajo druge načine zaznavanja. Če spremenimo paradigmo in spojine na osnovi amino skupin postanejo del senzorskega sloja in ne analizirane spojine, lahko te vrste materialov (polimeri, ogljikove nanocevke, ionske tekočine) uporabimo v senzorskih plasteh za zaznavanje $\mathrm{CO}_{2}$, kar je v celoti v skladu z merili HSAB. 